\title{
Klasifikasi Algoritma Swarm Intelligence dalam Perspektif Complex Adaptive System dengan Metode Uji Komparasi Statistik
}

\author{
Ketut Bayu Yogha Bintoro*), Silvester Dian Handy Permana \\ Program Studi Teknik Informatika, Fakultas Industri Kreatif dan Telematika, Universitas Trilogi \\ Jl. TMP Kalibata No. 1 Jakarta Selatan
}

Cara sitasi: K. B. Y. Bintoro, and S. D. H. Permana, "Klasifikasi Algoritma Swarm Intelligence dalam Perspektif Complex Adaptive System dengan Metode Uji Komparasi Statistik," Jurnal Teknologi dan Sistem Komputer, vol. 5, no. 4, pp. 166-171, Okt. 2017. doi: 10.14710/jtsiskom.5.4.2017.166-171, [Online].

\begin{abstract}
This research aims to classify which SI algorithms have CAS or non-CAS criteria. The statistical comparative test method with 5 (five) characteristic test parameters was used as the proof approach that produces the classification. Based on the hypothesis that has been tested from 15 (fifteen) algorithms compared in this study, It was obtained that 8 of 15 (53.33\%) algorithms has the majority of CAS characteristics, 3 of 15 (20\%) algorithms has a minority of characteristics of CAS, and 4 out of 15 (26.66\%) algorithms did not have CAS characteristics. The result can be a reference in understanding the characteristics of SI algorithms in the CAS and vice versa.
\end{abstract}

Keywords - Swarm intelligence algorithm; complex adaptive system; statistical comparison test

\begin{abstract}
Abstrak - Penelitian ini bertujuan mengklasifikasikan algoritma SI yang memiliki kriteria CAS ataupun tidak. Metode uji komparasi statistik dengan 5 (lima) parameter uji karakteristik CAS digunakan sebagai pendekatan pembuktian yang menghasilkan klasifikasi tersebut. Berdasarkan hipotesis yang telah diuji dan dibahas, dari 15 (lima belas) algoritma yang dibandingkan dalam penelitian ini, didapatkan 8 dari 15 (53,33\%) algoritma memiliki mayoritas karakteristik CAS, 3 dari 15 (20\%) algoritma memiliki minoritas karakteristik CAS, dan 4 dari 15 (26,66\%) tidak memiliki karakteristik CAS. Hasil tersebut dapat menjadi referensi teori dalam memahami karakteristik algoritma SI dalam CAS dan sebaliknya.
\end{abstract}

Kata Kunci - Algoritma swarm intelligence; complex adaptive system; uji komparasi statistik

\section{Pendahuluan}

Banyaknya algoritma yang berkembang di bidang Swarm Intelligence (SI) menuntut untuk dilakukan

\footnotetext{
*) Penulis korespondensi (K. B. Y. Bintoro)

Email: ketutbayu@trilogi.ac.id
}

klasifikasi algoritma [1]. Algoritma SI dapat digolongkan sebagai Complex Adaptive System (CAS) berdasarkan kesamaan karakteristik yang dimiliki SI terhadap CAS, salah satunya berdasarkan pada Standish [2]. Pada dasarnya, algoritma dalam SI memiliki karakteristik sebagai CAS. Namun, jika ditelaah lebih dalam dengan cara membandingkan karakteristik CAS terhadap suatu algoritma SI akan ditemukan beberapa karakter SI yang tidak sesuai dengan karakteristik CAS sehingga perlu dilakukan klasifikasi algoritma SI tersebut dalam kaitannya dengan CAS. Metode untuk melakukan proses klasifikasi juga menjadi salah satu hal penting yang diperhatikan.

Beberapa penelitian SI menekankan pada spesifik perilaku hewan yang menjadi sumber inspirasinya, yaitu antara lain algoritma rayap untuk menyelesaikan masalah clustering [3], algoritma pencarian serigala [4], algoritma optimalisasi kucing [5], strategi berburu elang [6], algoritma cuckoo search dan kunang-kunang [7], algoritma bacterial foraging [8], dan optimasi koloni rayap [9]. Penelitian tersebut perlu diuji untuk membuktikan apakah algoritma dalam rumpun SI tersebut merupakan bagian dari rumpun ilmu CAS atau tidak memiliki karakteristik sesuai dengan teori CAS walaupun dasar dari inspirasinya berasal dari interaksi kolektif mahluk hidup.

Klasifikasi SI sebagian besar dilakukan untuk memetakan SI berdasarkan mekanisme biomimetiknya [10]. Xiao dkk [11] melakukan pendekatan analisis kemiripan antara SI dan jaringan syaraf tiruan (JST). Penelitian ini bertujuan untuk mengklasifikasikan SI berdasarkan kesamaan karakteristiknya terhadap CAS. menempatkan algoritma SI tersebut menjadi objek yang akan diklasifikasikan dilihat dari sudut pandang CAS. Teknik uji komparasi digunakan sebagai pendekatan pembuktian. Uji komparasi algoritma akan digunakan untuk mengelompokkan beberapa algoritma dalam SI yang masuk ke dalam CAS dan algoritma mana saja yang tidak memiliki karakteristik CAS. 


\section{Metode Penelitian}

Metode yang digunakan dalam penelitian ini adalah metode uji komparasi statistik. Proses komparasi algoritma dilakukan dengan 4 (empat) tahapan, yaitu menentukan parameter ukur dari karakteristik CAS, membuat hipotesis komparatif dari sampel populasi, melakukan pengujian hipotesis dengan sampel bebas, dan melakukan uji hasil atau generalisasi hasil terhadap hipotesis awal. Pengujian hipotesis dilakukan dengan dua atau lebih sampel yang tidak saling berkorelasi satu dengan lainnya. Diagram alur metode uji komparasi statistik terdapat pada Gambar 1.

Klasifikasi algoritma SI pada penelitian ini mengacu pada penelitian yang dilakukan oleh Fister dkk. [1]. Algoritma SI tersebut tidak memiliki korelasi dengan teori CAS dan akan dibuktikan kecocokan karakteristik di antara keduanya. Distribusi 15 (lima belas) algoritma SI berdasarkan [1] dinyatakan dalam Tabel 1.

Semua algoritma akan diuji dengan parameter dan menjadi populasi. Dari populasi tersebut akan digeneralisasi untuk memperoleh kesimpulan akhir uji terhadap hipotesis. Penentuan parameter ukur diuraikan dalam Tabel 2 yang merupakan karakteristik CAS yang menjadi acuan dalam menentukan apakah SI termasuk ke dalam CAS atau tidak. Karakteristik CAS yang digunakan pada penelitian ini adalah berdasarkan Standish [2], yaitu sebagai berikut:

1. Jumlah entitas yang terlibat dalam interaksi (E);

2. Ada/tidaknya komunikasi;

3. Ada/tidaknya pola interaksi;

4. Pola pengetahuan internal;

5. Ada/tidaknya koordinator terpusat

Algoritma SI dalam Tabel 1 dibandingkan dengan karakteristik CAS sesuai Tabel 2. Hipotesis komparatif dinyatakan dengan dua sampel, yaitu $\mathrm{H}_{\mathrm{o}}$ dan $\mathrm{H}_{\mathrm{a}}$, dimana $\mathrm{H}_{\mathrm{o}}$ menyatakan bahwa tidak terdapat perbedaan dari dua sampel yang dibandingkan $\left(\mu_{1}=\mu_{2}\right)$ dan $H_{a}$ menyatakan bahwa terdapat perbedaan dari dua sampel yang dibandingkan $\left(\mu_{1} \neq \mu_{2}\right)$. Parameter $\mu_{\mathrm{i}}$ menyatakan kesamaan karakteristik algoritma SI dengan CAS.

\section{Hasil dan Pembahasan}

Hasil yang dicapai dalam proses komparasi antara 15 algoritma dalam SI dengan 5 karakteristik CAS sebagai parameter ukur ditunjukkan dalam Tabel 3. Dari 15 algoritma SI yang dibandingkan dengan 5 karakteristik CAS berdasarkan Fister dkk. [1], didapatkan bahwa 8 dari $15(53,33 \%)$ algoritma memiliki mayoritas karakteristik CAS, 3 dari 15 (20\%) algoritma memiliki minoritas karakteristik CAS, dan sisanya 4 dari 15 (26,66\%) tidak memiliki karakteristik CAS.

Uji komparasi statistik digunakan untuk mendapatkan hasil perbandingan dengan mengacu pada hipotesis awal yang telah ditentukan. Tabel 4 menunjukkan parameter hipotesis statistik dari masing-masing kelas yang telah

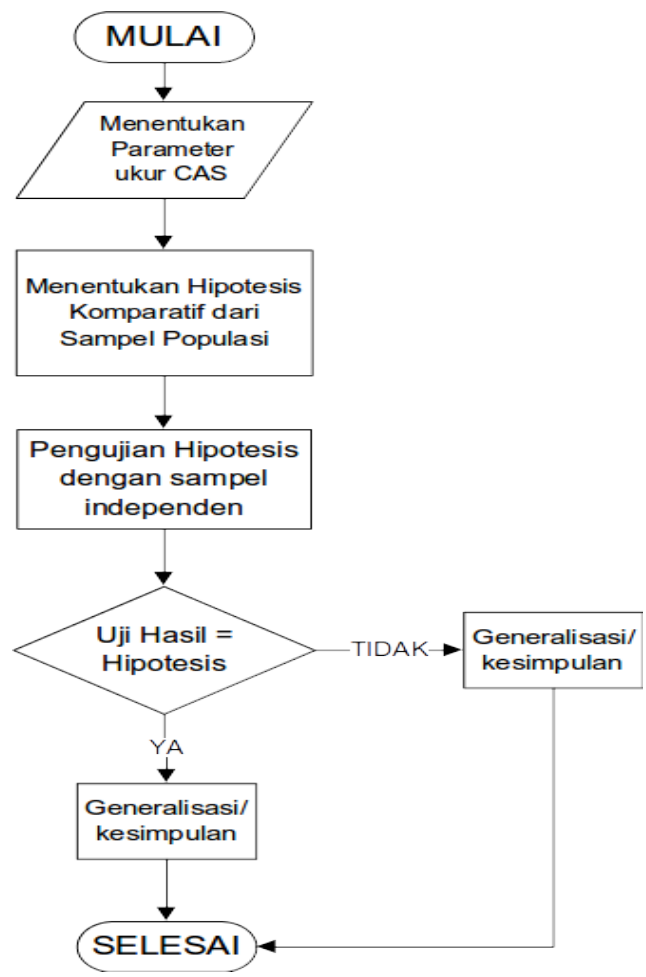

Gambar 1. Diagram alir metode uji komparatif statistik

Tabel 1. Klasifikasi algoritma SI [1]

\begin{tabular}{clc} 
No & \multicolumn{1}{c}{ Algoritma } & Reference \\
1 & Accelerated PSO (ACC PSO) & {$[12]$} \\
2 & Ant colony optimization $(A C O)$ & {$[13]$} \\
3 & Artificial bee colony $(A B C)$ & {$[14]$} \\
4 & Bacterial foraging $(B F)$ & {$[8]$} \\
5 & Bat algorithm $(B A)$ & {$[15]$} \\
6 & Wolf search $($ WS $)$ & {$[4]$} \\
7 & Cat swarm (CS) & {$[5]$} \\
8 & Consultant-guided search (CgS) & {$[16]$} \\
9 & Cuckoo search (CuS) & {$[7]$} \\
10 & Eagle strategy(ES) & {$[6]$} \\
11 & Firefly algorithm (FA) & {$[17]$} \\
12 & Fish swarm/school (FS) & {$[18]$} \\
13 & Glowworm swarm optimization & {$[19]$} \\
& GSO) & \\
14 & Hierarchical swarm model (HSM) & {$[20]$} \\
15 & Monkey search (MS) & {$[21]$}
\end{tabular}

ditentukan sebelumnya. H0 menunjukkan tingkat kecocokan algoritma SI terhadap CAS, sedangkan H1 menunjukkan tingkat ketidakcocokan algoritma SI terhadap CAS.

Berdasarkan hasil uji komparatif pada Tabel 3, diperoleh hasil 8 dari 15 algoritma (53,33\%) memiliki karakteristik CAS. Jika diperhatikan dari jumlah entitas, semua algoritma dalam kelompok ini, yaitu [8], [12]-[14], dan [17]-[20], memiliki jumlah entitas lebih dari satu dan 
Tabel 2. Karakteristik CAS dan parameter ukur

\begin{tabular}{|c|c|c|c|}
\hline No & Karakteristik CAS & Uraian & Parameter \\
\hline 1 & $\begin{array}{l}\text { Ketersediaan modul / } \\
\text { entitas CAS }\end{array}$ & $\begin{array}{l}\text { CAS terdiri dari multi modul/multi } \\
\text { entitas yang memiliki fungsi } \\
\text { sebagai unit kerja yang mendukung } \\
\text { CAS }\end{array}$ & Minimum terdiri dari 2 entitas \\
\hline 2 & Pola interaksi antar entitas & $\begin{array}{l}\text { Terdapat interaksi di antara entitas } \\
\text { baik secara langsung maupun tidak } \\
\text { langsung. Dibuktikan dengan } \\
\text { ketersediaan komunikasi antar } \\
\text { entitas }\end{array}$ & $\begin{array}{l}\text { Ada/tidaknya mekanisme komunikasi langsung } \\
\text { (entitas-entitas) atau } \\
\text { komunikasi tidak langsung (entitas-lingkungan- } \\
\text { entitas) }\end{array}$ \\
\hline 3 & $\begin{array}{l}\text { Integrasi kolektif } \\
\text { memunculkan pola/arah } \\
\text { pada level kelompok } \\
\text { (emergence behavior) }\end{array}$ & $\begin{array}{l}\text { Menghasilkan perilaku kolektif di } \\
\text { level kelompok. }\end{array}$ & $\begin{array}{l}\text { Terbentuk pola pada level kelompok } \\
\text { Ada dependency dan reliable }\end{array}$ \\
\hline 4 & $\begin{array}{l}\text { Kemampuan Adaptasi } \\
\text { modul/entitas terhadap } \\
\text { lingkungan (self-organize) }\end{array}$ & $\begin{array}{l}\text { Entitas memiliki kemampuan } \\
\text { adaptasi terhadap dinamika } \\
\text { lingkungan yang secara tidak } \\
\text { langsung mempengaruhi perilaku } \\
\text { secara kelompok }\end{array}$ & $\begin{array}{l}\text { Setiap entitas memiliki Rule/fungsional jelas. } \\
\text { Setiap entitas memiliki input -proses-output } \\
\text { yang jelas }\end{array}$ \\
\hline 5 & Koordinasi antar entitas & $\begin{array}{l}\text { Tanpa koordinator sentral yang } \\
\text { mengatur semua kegiatan/perilaku. }\end{array}$ & Tidak ada koordinator sentral \\
\hline
\end{tabular}

Tabel 3. Hasil komparasi algoritma SI dengan CAS

\begin{tabular}{|c|c|c|c|c|c|c|c|}
\hline & Algoritma & $\begin{array}{c}\text { Jumlah } \\
\text { entitas (E) }\end{array}$ & $\begin{array}{l}\text { Komunikasi } \\
(\mathbf{Y} / \mathbf{N})\end{array}$ & $\begin{array}{l}\text { Pola kolektif } \\
\qquad(\mathrm{Y} / \mathrm{N})\end{array}$ & $\begin{array}{l}\text { Pengetahuan } \\
\text { internal }(\mathrm{Y} / \mathrm{N})\end{array}$ & $\begin{array}{c}\text { Koordinator } \\
\text { terpusat }(\mathbf{Y} / \mathbf{N})\end{array}$ & Klasifikasi \\
\hline 1 & ACC PSO & $\mathrm{E}>1$ & $\mathrm{~N}$ & $\mathrm{Y}$ & $\mathrm{Y}$ & $\mathrm{N}$ & Mayor \\
\hline 2 & $\mathrm{ACO}$ & $\mathrm{E}>1$ & $\mathrm{Y}$ & $\mathrm{Y}$ & $\mathrm{Y}$ & $\mathrm{N}$ & Mayor \\
\hline 3 & $\mathrm{ABC}$ & $\mathrm{E}>1$ & $\mathrm{Y}$ & $\mathrm{Y}$ & $\mathrm{Y}$ & $\mathrm{N}$ & Mayor \\
\hline 4 & $\mathrm{BF}$ & $\mathrm{E}>1$ & $\mathrm{~N}$ & $\mathrm{Y}$ & $\mathrm{Y}$ & $\mathrm{N}$ & Mayor \\
\hline 5 & $\mathrm{BA}$ & $\mathrm{E}=1$ & $\mathrm{~N}$ & $\mathrm{~N}$ & $\mathrm{Y}$ & $\mathrm{N}$ & Nihil \\
\hline 6 & WS & $\mathrm{E}>1$ & $\mathrm{~N}$ & $\mathrm{Y}$ & $\mathrm{Y}$ & $\mathrm{Y}$ & Minor \\
\hline 7 & $\mathrm{CS}$ & $\mathrm{E}=1$ & $\mathrm{~N}$ & $\mathrm{~N}$ & $\mathrm{Y}$ & $\mathrm{N}$ & Nihil \\
\hline 8 & $\mathrm{CgS}$ & $\mathrm{E}>1$ & Tidak spesifik & $\mathrm{Y}$ & $\mathrm{Y}$ & $\mathrm{Y}$ & Minor \\
\hline 9 & $\mathrm{CuS}$ & $\mathrm{E}=1$ & $\mathrm{~N}$ & $\mathrm{~N}$ & $\mathrm{Y}$ & $\mathrm{N}$ & Nihil \\
\hline 10 & $\mathrm{ES}$ & $\mathrm{E}=1$ & $\mathrm{~N}$ & $\mathrm{~N}$ & $\mathrm{Y}$ & $\mathrm{N}$ & Nihil \\
\hline 11 & FA & $\mathrm{E}>1$ & $\mathrm{Y}$ & $\mathrm{Y}$ & $\mathrm{Y}$ & $\mathrm{N}$ & Mayor \\
\hline 12 & $\mathrm{FS}$ & $\mathrm{E}>1$ & $\mathrm{~N}$ & $\mathrm{Y}$ & $\mathrm{Y}$ & $\mathrm{N}$ & Mayor \\
\hline 13 & GSO & $\mathrm{E}>1$ & $\mathrm{Y}$ & $\mathrm{Y}$ & $\mathrm{Y}$ & $\mathrm{N}$ & Mayor \\
\hline 14 & HSM & $\mathrm{E}>1$ & Tidak spesifik & $\mathrm{Y}$ & $\begin{array}{l}\text { Y, Tergantung jenis } \\
\text { populasi swarm }\end{array}$ & $\mathrm{N}$ & Mayor \\
\hline 15 & MS & $\mathrm{E}>1$ & $\mathrm{~N}$ & $\mathrm{~N}$ & $\mathrm{Y}$ & $\mathrm{N}$ & Minor \\
\hline
\end{tabular}

Keterangan:

Nilai Y menunjukkan ada dan N menunjukkan tidak ada. Mayor menyatakan SI mempunyai minimal 3 karakteristik CAS, Minor mempunyai 1-2 karakteristik CAS dan Nihil tidak memiliki karakteristik CAS.

tidak adanya koordinator terpusat yang menentukan pola interaksi pada saat proses adaptasi terjadi. Hal ini menunjukkan bahwa karakteristik ini menjadi ciri utama dari CAS secara mendasar. Pola interaksi yang terbentuk dari lebih dari satu entitas tanpa koordinator tunggal tersebut diinisiasi oleh adanya mekanisme komunikasi secara langsung ataupun tidak langsung.

Ditinjau dari sisi komunikasi terdapat perbedaan strategi komunikasi yang digunakan masing-masing koloni hewan. ACO [13] menggunakan feromon dan memanfaatkan media lingkungan sebagai penghantar komunikasi dengan entitas lainnya, sedangkan ACC PSO [12] menggunakan kemampuan visual dalam mengukur jarak, menghindari tabrakan dan mengikuti pergerakan tetangga untuk mencapai solusi yang harapkan.

Untuk melakukan komunikasi baik mengirim dan menerima pesan komunikasi, algoritma tersebut, kecuali HSM [14], dilengkapi dengan pengetahuan internal yang spesifik sesuai dengan acuan kelompok hewan yang dipakai. Pengetahuan internal tersebut umumnya sederhana dan menggambarkan kemampuan entitas dalam merespons lingkungannya. Algoritma HSM [14] 
Tabel 4. Parameter uji komparatif hipotesis

\begin{tabular}{ccl}
\hline No & Klasifikasi & Parameter uji Hipotesis Komparatif \\
\hline 1 & Mayor & $\mathrm{H}_{0}, 3<=$ Karakteristik Algoritma $\operatorname{SI}\left(\mu_{1}\right)=$ \\
& 5 \\
& & $\mathrm{H}_{1}, 0>=$ Ketidakcocokan Karakteristik \\
& Algoritma SI $\left(\mu_{1}\right)=2$ \\
& Minor & $\mathrm{H}_{0}, 1<=$ Karakteristik Algoritma SI $\left(\mu_{2}\right)$ \\
& $<=2$ \\
& & $\mathrm{H}_{1} 3>=$ Ketidakcocokan Karakteristik \\
& & Algoritma SI $\left(\mu_{2}\right)=4$ \\
& Nihil & $\mathrm{H}_{0}$, Karakteristik Algoritma SI $\left(\mu_{3}\right)=0$ \\
& & $\mathrm{H}_{1}, 4>=$ Ketidak-cocokan Karakteristik \\
& Algoritma SI $\left(\mu_{3}\right)=5$
\end{tabular}

terinspirasi dari berbagai algoritma SI yang disusun secara hierarki sehingga pola komunikasi yang terbentuk tidak spesifik secara umum tergantung dari jenis koloni yang dijadikan acuan.

Pola komunikasi yang tidak spesifik pada HSM berpengaruh terhadap pengetahuan internal entitas. Pada HSM pengetahuan internal juga tidak spesifik karena tergantung dari jenis koloni hewan yang dijadikan acuan dan pola komunikasi yang digunakan koloni hewan tersebut. HSM merupakan model hierarki dari pola interaksi kelompok sehingga algoritma apapun dalam SI dapat dimodelkan secara hierarki. Atas dasar itu dapat dinyatakan bahwa HSM bukanlah kelompok algoritma SI.

Penelitian ini menggunakan terminologi mayoritas atau minoritas kesamaan pada terhadap $\mu_{\mathrm{n}}$ (Tabel 4) karena kesamaan karakteristik perbandingan tidak harus $100 \%$. Hal ini disebabkan karena setiap algoritma memiliki karakteristik unik yang sangat berbeda satu dengan yang lainnya. Penelitian ini tidak menjustifikasikan kesamaan mutlak antara algoritma SI terhadap CAS tetapi menggunakan prinsip-prinsip utama dalam CAS yang menjadi ciri yang ditemukan pada algoritma SI seperti komunikasi, jumlah entitas, pola interaksi dan ada atau tidaknya koordinator pada pola interaksi. Terminologi tersebut berlaku pada ketiga klasifikasi yang dihasilkan sesuai dengan Tabel 3.

Terminologi minoritas kesamaan yang digunakan pada kelompok kedua pada Tabel 3 juga mengacu pada prinsip-prinsip utama dalam CAS yang menjadi ciri yang ditemukan pada algoritma SI dengan jumlah kesamaan yang lebih sedikit yaitu $1<=\mu_{2}<=2$ dimana $\mu_{2}$ adalah kesamaan karakteristik algoritma SI.

Pada kelompok kedua ini (Minor), terdapat minimal 1 dan maksimal 2 perbedaan prinsip dengan karakteristik CAS. Jumlah entitas pada ketiga algoritma dalam kelompok ini, yaitu [4], [16], dan [21], terdiri dari lebih dari satu entitas (E). Perbedaan mendasar terlihat pada pola komunikasi di antara ketiga algoritma tersebut. Walaupun jumlah entitas lebih dari satu, namun tidak terjadi komunikasi di antara anggota koloni, misalnya algoritma WS [4] menggunakan kemampuan sensor penciuman dan visual untuk menangkap mangsa (solusi) terbaik tetapi tidak ada strategi yang terbangun dari komunikasi di antara koloni serigala. Pada algoritma WS ini inisialisasi posisi dan penempatan posisi terhadap mangsa lebih menentukan tingkat keberhasilan perburuan.

Algoritma $\mathrm{CgS}$ [16] justru melibatkan adanya koordinator (konsultan) yang mengoordinasikan kelompok agen yang ada di bawahnya. Kasus ini memperlihatkan adanya komunikasi dengan strategi yang berbeda-beda antara kelompok konsultan dalam kelompok besar. Pola komunikasi spesifik pada $\mathrm{CgS}$ tidak terlihat, namun tetap terjadi pola interaksi secara kelompok besar dari interaksi dan perbedaan kelompok kecil penyusun yang dipimpin oleh satu konsultan dan beberapa agen di bawahnya.

Strategi berbeda digunakan pada MS [21]. Pada MS, solusi dihasilkan dari masing-masing individu monyet dalam mencari cabang pohon dengan jumlah makanan yang optimal dibandingkan dengan upaya yang dikeluarkan. Tidak ada pola komunikasi eksplisit pada MS karena pemilihan ranting terbaik (solusi) dilakukan dengan pendekatan probabilitas dan iterasi sehingga solusi yang terpilih memiliki probabilitas terbaik dan setelah melewati iterasi secara berulang. Masing-masing individu monyet bergerak secara mandiri, tidak ada pola interaktif di antara individu monyet secara langsung.

Pada kelompok terakhir (Nihil), algoritma SI yang tidak termasuk ke dalam CAS karena memiliki paling sedikit kesamaan dari karakteristik CAS, namun bukanlah karakteristik utama seperti yang telah dijabarkan sebelumnya. Empat algoritma $(26,66 \%)$ dari lima belas algoritma SI termasuk ke dalam kategori ini, yaitu [5]-[7] dan [15]. Algoritma SI yang masuk ke dalam kelompok ini memiliki ciri kompleksitas yang terjadi di level individu bukan pada level kelompok. Secara prinsip karakteristik SI meminimalkan kompleksitas di sisi individu / entitas agen tetapi menghasilkan kompleksitas pada level kelompok/grup. Berdasarkan tersebut tersebut, dapat disimpulkan bahwa keempat algoritma yang masuk dalam kategori ini bukanlah termasuk dalam kelompok algoritma SI sehingga tidak termasuk ke dalam CAS berdasarkan kelima parameter yang digunakan dalam penelitian ini.

Berdasarkan uraian di atas, dapat dibuktikan bahwa tidak semua algoritma SI yang memiliki karakteristik CAS, seperti algoritma [5]-[7] dan [15]. Hasil tersebut menambah pengetahuan yang diperoleh dari penelitian yang dilakukan oleh Fister dkk. [1] yang di dalamnya mengungkapkan perlunya melihat perspektif klasifikasi algoritma SI, bio-inspired algorithm (BIA), dan natural inspired algorithm dari sudut pandang CAS. Selain itu, penelitian ini telah memberikan sisi lain pemetaan SI berdasarkan karakteristik CAS, seperti [10] yang memetakan berdasarkan mekanisme biomimetik dan [11] yang menganalisis SI dan JST. Hasil perbandingan tersebut diharapkan dapat membantu peneliti menempatkan secara tepat dalam penelitiannya kapan 
menggunakan kedua istilah tersebut secara proporsional dan bagaimana keterkaitan antara algoritma yang dipilih dalam penelitian terhadap CAS sehingga penggunaan istilah CAS dalam penelitian SI menjadi jelas dan tidak bias.

\section{KESIMPULAN}

Berdasarkan hipotesis yang telah diuji dan dibahas, kami menyimpulkan bahwa memang dari kelima belas algoritma yang dibandingkan, terdapat beberapa algoritma SI yang tidak termasuk ke dalam CAS berdasarkan lima parameter yang digunakan dalam uji komparasi statistik. Sangatlah sulit untuk mendefinisikan secara lengkap dan eksplisit tentang CAS sehingga pada penelitian ini digunakan karakteristik parsial dalam konteks yang sesuai dengan Swarm Intelligence. Demikian juga dengan jumlah algoritma SI yang bisa dibandingkan, sangatlah sulit untuk dapat memastikan secara tepat ratusan algoritma yang terinspirasi dari koloni hewan mengingat luasnya sumber referensi yang dapat diakses dan perkembangan ilmu SI yang terus berkembang. Penelitian selanjutnya dapat dikembangkan dengan menerapkan parameter CAS yang lebih luas dan jumlah algoritma SI yang diuji semakin banyak. Parameter yang lebih banyak akan lebih menggambarkan karakteristik sebenarnya dari CAS terutama dilihat dari rumpun ilmu SI.

\section{UCAPAN TERIMA KASIH}

Terima kasih kepada Program Studi Teknik Informatika Universitas Trilogi yang telah mengakomodasi keperluan uji statistik dan laboratorium komputer sehingga penelitian ini dapat terselesaikan.

\section{Daftar Pustaka}

[1] I. Fister Jr. S. X. Yang, I. Fister, J. Brest, and D. Fister, "A Brief Review of Nature-Inspired Algorithms for Optimization," ELEKTROTEHNI'SKI VESTNIK, vol. 80, no. 3, pp. 116-1227, 2013.

[2] K. R. Standish, Concept and Definition of Complexity, in Intelligent Complex Adaptive Systems, IGI Global, Hershey, 2008.

[3] R. Reddy, and S. Kalavathi, "Termite Colony Optimization Algorithm for Solving Optimal Reactive Power Dispatch Problem," International Journal of Research in Electronics and Communication Technology, vol. 1, no. 4, pp. 34-42, 2014.

[4] R. Tang, S. Fong, S. X. Yang, and S. Deb, "Wolf search algorithm with ephemeral memory," in 7th International Conference on Digital Information Management (ICDIM 2012), 2012, pp. 165-172. doi: 10.1109/ICDIM.2012.6360147.
[5] Y. Liu, X. Wu, and Y. Shen, "Cat Swarm Optimization Clustering (KSACSOC): A Cat Swarm Optimization Clustering Algorithm", Scientific Research and Essays, vol. 7, no. 49, pp. 4176-4185, 2012.

[6] S. X. Yang, and S. Deb, "Eagle Strategy using Levy Walk and Frefly Algorithms for Stochastic Optimization", in Nature Inspired Cooperative Strategies for Optimization (NICSO2010), 2010. pp. 101-111. Springer Berlin Heidelberg.

[7] S. K. Fateen, and A. Bonilla-petriciolet, "Cuckoo Search and Firefly Algorithm," Studies in Computational Intelligence, vol. 516, pp. 315-330, 2014. doi: 10.1007/978-3-319-02141-6.

[8] S. Das, A. Biswas, S. Dasgupta, and A. Abraham, "Bacterial Foraging Optimization Algorithm: Theoretical Foundations, Analysis, and Applications," Foundations of Computational Intelligence, vol. 3, no. 3, pp. 23-55, 2009. doi: 10.1007/978-3-642-01085-9_2.

[9] K. B. Yogha, M. Cendana, and R. Lipikorn, R. (2017) 'Non-deterministic Finite State Automata as Termites swarm Agent Model', in 2017 7th International Workshop on Computer Science and Engineering (WCSE), 2017.

[10] J. Ni, L. Wu, X. Fan, and S. X. Yang, "Bioinspired Intelligent Algorithm and its Applications for Mobile Robot Control: a Survey," Computational Intelligence and Neuroscience, vol. 2016. doi: $10.1155 / 2016 / 381090$.

[11] R. Xiao, Z. Tao, and T. Chen, "An Analytical Approach to the Similarities between Swarm Intelligence and Artificial Neural Network," Transactions of the Institute of Measurements and Control, vol. 34, no. 6, pp. 736-745, 2011.

[12] S. X. Yang, S. Deb, and S. Fong, "Accelerated Particle Swarm Optimization and Support Vector Machine for Business Optimization and Applications," in the Third International Conference on Networked Digital Technologies (NDT 2011), Networked Digital Technologies, Communications in Computer and Information Science, Jul. 2011, v. 136, p. 53-66.

[13] M. Dorigo, and T. Stutze, Ant Colony Optimization. MIT Press, ISBN 0-262-04219-3, England, 2004.

[14] D. Karaboga, and B. Basturk, "On the Performance of Artificial Bee Colony (ABC) Algorithm," Applied Soft Computing, vol. 8, no. 1, pp. 687-697, 2008. doi: 10.1016/j.asoc.2007.05.007.

[15] S. X. Yang, and X. He, "Bat Algorithm: Literature Review and Applications," International Journal of Bio-Inspired Computation, vol. 5, no. 3, pp. 141149, 2013. doi: 10.1504/IJBIC.2013.055093.

[16] S. Iordache, "Consultant-Guided Search Algorithms with Local Search for the Traveling Salesman 
Problem', in Parallel Problem Solving from Nature XI, 2010, pp. 81-90.

[17] S. X. Yang, "Firefly Algorithms for Multimodal Optimization," in International Symposium on Stochastic Algorithms, Berlin, 2009, pp. 169-178.

[18] M. Neshat, A. Adeli, G. Sepidnam, M. Sargolzaei, and A. N. Toosi, "A Review of Artificial Fish Swarm Optimization Methods and Applications," International Journal on Smart Sensing and Intelligent Systems, vol. 5, no. 1, pp. 107-148, 2012.

[19] K. N. Krishnanand, and D. Ghose, "Glowworm Swarm Optimization for Simultaneous Capture of
Multiple Local Optima of Multimodal Functions," Swarm Intelligence, vol. 3, no. 2, pp. 87-124, 2009. doi: 10.1007/s11721-008-0021-5.

[20] H. Chen, Y. Zhu, K. Hu, and X. He, "Hierarchical swarm model: A new approach to optimization," Discrete Dynamics in Nature and Society, vol. 2010, 2010. doi: 10.1155/2010/379649.

[21] C. M. Ituarte-Villarreal, N. Lopez, and J. F. Espiritu, "Using the Monkey Algorithm for Hybrid Power Systems Optimization," Procedia Computer Science, vol. 12, pp. 344-349, 2012. doi: 10.1016/j.procs.2012.09.082. 